\title{
O CASO DOS BATUQUES EM RECIFE NO SÉCULO XVIII: africanos, italianos e portugueses em conflito
}

\author{
Josinaldo Sousa de Queiroz*
}

\begin{abstract}
RESUMO: apresentamos uma discussão sobre as expressões culturais africanas realizadas na Capitania de Pernambuco vistas a partir do discurso produzido pela administração colonial e pela Igreja Católica Romana. Procuramos entender, por meio da análise da documentação oficial produzida nos últimos vinte anos do século XVIII, no âmbito do Conselho Ultramarino e do Tribunal da Inquisição de Lisboa, como essas práticas (danças, festas, batuques, feitiços, mandingas) influenciavam não apenas o cotidiano dos seus protagonistas - os africanos e seus descendentes -, mas também o dos colonos, das pessoas ligadas à administração religiosa e dos agentes ligados à administração colonial.
\end{abstract}

PALAVRAS-CHAVE: Liberdade; Escravos; Batuques; Inquisição.

\section{The case of batuques in Recife 18th century: africans, italians and portugueses in conflict}

\begin{abstract}
We present a discussion about african culture expression. Performed at Captaincy of Pernambuco seen by the discourse produced at the colonial management and at the Roman Catholic Church. We try to understand by analysing official documentation produced in the last twenty years of 18th century, by Overseas Council and Inquisition Court of Lisbon with these practices (dances, festivities, batuques, charms, mandingas) influenced not only dailylife of theirs protagonists - the africans and their descendentes -, but also settlers people of the religious management and agents of the colonial management.
\end{abstract}

KEYWORDS: Freedom; Slaves; Batuques; Inquisition.

\section{El caso de los batuques en Recife en el siglo XVIII: africanos, italianos y portugueses en conflito}

RESUMEN: Presentamos una discusión sobre las expresiones culturales africanas realizadas en la Provincia de Pernambuco vistas a partir del discurso producido por la administración colonial y por la Iglesia Católica Romana. Buscamos comprender, a través del análisis de la documentación oficial producido en los últimos veinte años del siglo XVIII, en el marco del Consejo de Ultramar y del Tribunal de la Inquisición de Lisboa, como tales prácticas (bailes, fiestas, batuques, hechizos, mandingas) influyeron no tan solo el cotidiano de sus protagonistas - los africanos y sus descendientes -, pero también la vida de los colonos, personas vinculadas a la administración religiosa y agentes de la administración colonial.

PALABRAS CLAVE: Libertad; Esclavos; Batuques; Inquisición.

\footnotetext{
* Mestre em História pela Universidade Federal de Pernambuco. Atualmente, doutorando em História pelo Programa de Pós-Graduação em História da mesma Universidade. Contato: Universidade Federal de Pernambuco, Centro de Filosofia e Ciências Humanas, 10. andar, Cidade Universitária, CEP: 50740-550, Recife - PE, Brasil. E-mail: josinaldoprojetocatalogo@gmail.com. ORCID: http://orcid.org/0000-0001-7533-875X.
} 
Para a construção do presente texto, utilizamos documentos gestados pelo Tribunal do Santo Ofício e do Arquivo Histórico Ultramarino ${ }^{1}$. Também usamos a descrição dos reinos do Congo, Matamba e Angola, deixada pelo missionário Capuchinho Cavazzi. No que se refere aos documentos inquisitoriais ${ }^{2}$, usamos os processos movidos pelo Tribunal religioso e denúncias feitas aos agentes inquisitoriais.

Quanto aos documentos produzidos no âmbito do Conselho Ultramarino, trata-se de ofícios e cartas escritas pelo Governador de Pernambuco, José César de Meneses. Serão usados, também, documentos redigidos pela missão dos Capuchinhos italianos, ordens enviadas pela Rainha de Portugal, D. Maria I, e um parecer escrito pelo antigo Governador de Pernambuco, o Conde de Povolide.

Para tanto, norteamos nossa análise a partir de bibliografia especializada sobre o tema dedicada aos estudos sobre a diáspora africana e as suas consequências no chamado Novo Mundo. Priorizamos discutir como essas práticas empregadas pelos sujeitos escravizados criavam relações constantes de barganhas, reivindicando seus espaços de liberdades por meio de suas práticas culturais, indo, dessa maneira, contra as ações empregadas sobre estas práticas.

\section{Cultura africana denunciada à Inquisição: o caso dos batuques no Recife}

Em documento expedido em 23 de abril de 1778, consta a "Relação dos Missionários

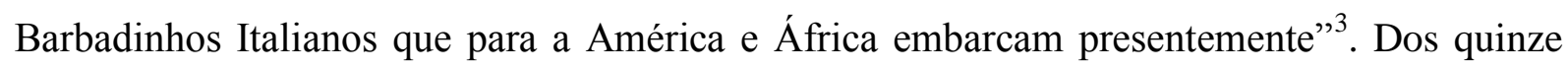
missionários embarcados, quatro tiveram como destino a Capitania de Pernambuco: Frei Constantino de Parma (posteriormente viria a ser o Prefeito das Missões), Frei Pedro de Bregossia, Frei Clemente de Moreta e Frei Pedro Lourenço de Loussalo. A mesma relação fora expedida no dia 28 de abril de 1778 para o Governador e Capitão General da Capitania de Pernambuco, José César, constando a mesma informação assinada por João Gomes de Araújo, "Oficial Maior desta Secretaria de Estado dos Negócios da Marinha e Domínios Ultramarinos, [...] declarando haver a mesma senhora [D. Maria I] permitido o seu Real Beneplácito ${ }^{4}$.

Saíram às ruas de Recife, em 21 de dezembro de 1778, "levados do seu Apostólico espírito", os quatro Capuchinhos recém-chegados da corte, a mando de D. Maria I, Rainha de Portugal, e mais cinco sacerdotes do Hospício de Recife. Empenharam-se em dar um fim a danças e a batuques feitos por negros em praça pública. Para tanto, não pouparam esforços 
invadindo casas, quebrando e queimando instrumentos. Por onde os fervorosos sacerdotes passavam, "ensinava o povo, a força de carões, com um Santo Cristo".

Apesar da documentação não citar muitos detalhes sobre a vivência dos escravos livres e libertos em Pernambuco, percebemos, através das atitudes dos missionários citados acima que era comum os festejos e ritos religiosos de matriz africana e afro-brasileira na Capitania. Como veremos adiante, africanos e negros nascidos no Brasil, cotidianamente, empreendiam seus costumes aos olhos das autoridades administrativas e religiosas da colônia. Para Kalina Vanderlei Silva ${ }^{6}$, Recife no século XVIII "era lar de uma extensa rede de agremiações de livres e escravos, composta por irmandades leigas e corporações de ofícios". Logo, não é difícil imaginar que as suas ruas e outras vilas e cidades de Pernambuco carregassem fortes traços da cultura afro e afro-brasileira.

Alguns negros se queixaram ao Governador e Capitão General de Pernambuco, José César de Meneses (1774-1787), sobre o ocorrido e justificaram suas danças por possuírem licença por ele escrita ${ }^{7}$. Não obstante, José César puniu os missionários Capuchinhos, obrigando-os a pagarem o desmanche dos instrumentos, sob pena de remetê-los para o reino “como perturbadores da República"8. Dois anos após o ocorrido, no dia 22 de março de 1780, o Governador escreveu em um ofício para o Secretário do Conselho Ultramarino, Martinho de Melo e Castro, sobre a resposta que havia dado a uma carta recebida do Tribunal da Santa Inquisição, que tratava das danças e das cerimônias feitas pelos negros africanos, em especial, dos vindos da Costa da Mina, escravos domiciliados em Recife, Capitania de Pernambuco.

Em resposta, José César mostrou-se contrário às atitudes de repressão e de proibição impostas pelos Capuchinhos aos negros da Capitania, que dançavam em seu dia de folga. Segundo ele, dizia ter o "coração inteiramente católico pronto para proteger qualquer pessoa eclesiástica e aqueles que promulgavam a palavra de Deus", mas não poderia permitir que missionários usassem de força ao invés da persuasão [com os negros] ${ }^{9}$.

O caso citado acima, de certa forma, é conhecido na historiografia pernambucana, apesar de haver alguns estudos sobre o tema, sempre usarem a mesma fonte e pouca problematização da presença dos escravos na documentação ${ }^{10}$. Estas pesquisas enfatizaram à atitude de um Governador em permitir tais expressões do que propriamente o protagonismo daqueles sujeitos relegados ao cativeiro, que sabiam, nas malhas de um sistema excludente burlar os olhares vigentes da época e colocar em prática suas expressões culturais.

José Antônio Gonsalves de Mello escreveu um pequeno texto sobre o caso e citou algumas fontes até então desconhecidas. Na época, fez algumas associações com os ritos afro- 
brasileiros em Pernambuco no século XX e os batuques do século XVIII ${ }^{11}$. Rita de Cássia B. de Araújo escreveu um artigo sobre o tema, articulando-o com as festas públicas na colônia portuguesa. Apesar disso, a autora não teve acesso a outras fontes que apresentaremos, e acabou por dar mais ênfase à atitude conciliadora do Governador em permitir os batuques e não problematizou e discorreu sobre outros assuntos presentes na documentação. Ela reconhece, assim, como Gonsalves de Mello, que o caso necessita de um reexame para melhor compreensão, e cita Luís Geraldo Silva Filho, que estava estudando o mesmo episódio ${ }^{12}$.

O texto de Silva Filho trouxe um novo olhar sobreo tema. Seu artigo se divide em várias partes, em que faz uma incursão por várias regiões da África, com o objetivo de explicar algumas etnias que viviam em Pernambuco. $\mathrm{O}$ autor também problematizou o cotidiano de algumas irmandades de Olinda e de Recife e, por fim, explorou a ideia de controle social através do caso dos batuques, que ocorrera na capitania em fins do século $\mathrm{XVIII}^{13}$. Existem outros textos que discutiram esse caso, mas todos sempre se referem ao mesmo tema: a permissividade para com os ritos afro e africanos e a ideia de resistência por parte dos escravos. Obviamente concordamos com esta visão, mas nossa pesquisa pretende apresentar novos aspectos sobre o episódio que ficou conhecido na historiografia pernambucana.

Em nossas pesquisas, nos depararemos com a denúncia original elaborada por um sacerdote sobre o caso dos batuques em Recife. Trata-se de uma diligência que acabou não sendo levada à frente pelo Tribunal do Santo Ofício, ou seja, não teve relevância para se instaurar um processo para averiguação da situação da denúncia, arrolamento de testemunhas e punição de quem fosse considerado culpado. Apesar disso, as poucas páginas que compõem o documento possuem informações que podem nos ajudar a entender e a problematizar as vivências escravas em Pernambuco.

Em carta para o Santo Ofício, o sacerdote do Hábito de São Pedo Domingos Oliveira Marques escreveu para o referido Tribunal "que os pretos vindos a Pernambuco do gentio de Angola, e outros distritos, se ajuntam e executam umas danças acompanhadas de ritos gentílicos, com que aqueles bárbaros adoram suas falsas divindades"14. Por considerarem danosas "ao bom proveito das almas",

Chegados os Reverendos Missionários Capuchinhos a esta terra [de Pernambuco], mandados pela nossa Fidelíssima Rainha, informados, e vendo as sobreditas danças, máximo a dos negros, começaram a invadir fervorosamente dos púlpitos contra elas, e levados do seu Apostólico espírito no dia vinte e um de dezembro de 1778 saíram do Hospício, acompanhados de cinco sacerdotes seculares e pelos lugares, que thes 
ensinava o povo, a força de carões, com um Santo Cristo reduziram a uns a entregar a alguns dos ditos instrumentos, que o povo pelo dito dos Missionários quebraram, queimaram ${ }^{15}$.

Após o ocorrido, os negros queixaram-se ao governador, e o mesmo concedera licença por escrito aos queixosos das ações dos missionários. Além disso, mandou intimar ordem aos ditos religiosos para "cessarem de tal fato sob pena de os remeter para Lisboa" como “perturbadores da República”. Fora isso, todos os sacerdotes que se empenharam na perseguição e destruição dos instrumentos tiveram que pagar 3 mil réis para refazerem os tambores, marimbas, citáras etc. Os negros, por sua vez, saíram as ruas com cantigas, escarniando dos ditos religiosos e "solenizaram as festas do Santo Natal seguinte com especial concurso deles as tais danças”. Além disso, um deles, por tal embaraço que se fizera com a perseguição dos capuchinhos, tentou "embarcar para Lisboa para dar conta a nossa fidelíssima Rainha”, mas fora atrapalhado e não conseguira embarcar.

A segunda denúncia inclusa na diligência contém algumas informações úteis para compreendermos como ocorriam os rituais africanos, supostamente em praça pública

\begin{abstract}
Se deve primeiro saber, que neste Pernambuco se tem introduzido os negros gentios batizados suas danças das suas terras, com que lá adoram, e festejam aos seus falsos deuses, acompanhados de instrumentos gentílicos, tabaques, que são como espécie de tambor, marimbas e outros de ferro, todos estrondosos, horríveis, tristes, e desentoados, próprios do inferno, e certas cantilenas na sua língua gentílica, as quais em todos os domingos e dias santos do ano fazem, e se coloram com título de tirarem esmolas para Nossa Senhora, e para mandarem dizer missas pelas almas dos que morreram daquela sociedade e o fazem com certa mesa coberta com rito também gentílico: o que deve causar todo o reparo, e atenção, pois se acham em terra cristã, e eles batizados. ${ }^{16}$
\end{abstract}

Apesar da denúncia deixar bem evidente a repulsa que havia por parte dos missionários Capuchinhos sobre as danças dos negros, alguns aspectos merecem ser analisados para entendermos de que se tratavam os rituais em questão. Chamamos a atenção para a preocupação do religioso Domingos em apontar que os negros eram batizados, adoravam a outros deuses e retiravam esmolas para as missas.

Essa constatação do batismo nos traz possíveis informações de quem eram esses negros. Primeiro, parte dos africanos denunciados vinham de regiões centro-africanas, que atualmente constituem Angola, Congo, Gabão e Cabinda. As pessoas deslocadas destes locais trouxeram uma cosmovisão muito particular e divergente da que se formara na colônia sob a égide (pelo menos em tese) do catolicismo europeu. Para estes sujeitos e tantos outros africanos, o mundo estava dividido em dois seguimentos: o plano material (dos vivos) e o plano imaterial (dos mortos). Significava a troca constante de informações entre os dois 
mundos, em que o primeiro dependia do segundo para obter informações, resolver conflitos e outras situações do dia a dia.

Uma das características dos centro-africanos "era a crença de que as estruturas seculares estavam intimamente ligadas às ideias religiosas. As ideologias políticas, sociais, econômicas e culturais estavam todas integradas numa cosmologia"17. Esta cosmologia servia de parâmetro para o comportamento e para a execução de rituais, explicava a origem de doenças e outros fatores desagradáveis, assim como desenhavam as relações entre o ser humano e as divindades.

Dessa forma, estes dois mundos estavam divididos por uma grande quantidade de água que deveria ser atravessada por aqueles que morriam ${ }^{18}$. Apesar da travessia feita por parentes ou malungos, havia uma certa dinâmica entre os que ficaram no mundo dos vivos e aqueles que partiram para o plano espiritual, estabeleciam-se relações que conectavam ambos os planos através de rituais, onde ofertavam comida ao espírito do falecido e faziam o contato para a obtenção de respostas ou para se resolver conflitos familiares e comunitários.

Cabe ressaltar que na região de Angola a introdução do culto católico romano remonta ao final do século XV. A omissão do denunciante negligencia uma parte importante da história da África, particularmente no reino do Congo, ao enfatizar que, por serem "cristãos", não poderiam realizar tais atos. O Cristianismo havia sido disseminado no Congo em finais do século XV, e naquela região ocorreu a aceitação do catolicismo por parte dos reis congoleses. Não obstante, a "utilização do Cristianismo como instrumento de poder distinguia o reino do Congo de todos os outros da região não só aos olhos dos portugueses e europeus [...], mas também para os povos vizinhos ${ }^{19}$.

Observamos tal situação com a finalidade de evidenciarmos que a implantação do Cristianismo, o uso do batismo ou qualquer outra prática católica romana não era sinônimo, ao menos para os africanos, de abandono de crenças anteriores. O missionário Cavazzi apontava que "neste reino existe maus cristãos" 20 , referindo-se aos iniciados nos dogmas católicos romanos que preservavam suas crenças animistas.

$\mathrm{Na}$ denúncia observamos que as visões religiosas dos africanos denunciados estavam em constantes mudanças e adaptações. Se na África o catolicismo fora utilizado como estrutura de prestígio e poder, assim como substituição do animismo religioso ou complementação de suas crenças, em Pernambuco, seguiu-se a mesma lógica. Apesar disso, não significa que fosse uma continuidade do que viveram antes da captura e da escravização, 
mas sim uma forma de sobrevivência e de adaptação na qual tinham de se inserir para seguirem o curso da nova vida.

Claro que não descartamos a presença de africanos que abandonaram suas antigas crenças e passaram a seguir os ditames da Igreja de Roma. Existiram, mas, ainda assim, estes sujeitos partiam de suas antigas vivências para compreender esse novo mundo, como foi o caso da correlação entre o nzambi mpugu ${ }^{21}$ (deus do alto) e o Deus cristão. Infelizmente, não dispomos de registros mais completos que atestem a cosmovisão dos centro-africanos, em que pese a utilização de uma ou mais vivências religiosas que elucidem nossos questionamentos de forma satisfatória. Apesar disso, alguns fragmentos textuais possibilitam algumas considerações sobre o que passou desapercebido ao denunciante.

Ainda na denúncia feita ao Santo Ofício, foi descrito que os negros "fazem na terra pelos naturais, chamadas Fofa, ou Batuque entre homens, e mulheres, que consiste em representar um ato torpe de fornicação, acompanhada de instrumentos, estrépitos de pés, e mãos", e que "para maior desgraça nos tempos presentes com ditos blasfemos como "Oh meu Deus, ora vamos para o céu",22. Esse trecho, apesar de poucas informações, contém várias percepções implícitas que, à primeira vista, são desapercebidas. Apenas recapitulando, a denúncia nos fala de negros de Angola e Costa da Mina. Sabemos que estas duas regiões possuem especificidades religiosas distintas. Quando se referiam à batuques e à preces a "Deus", é possível inferirmos que falava dos angolanos, dada a proximidade com o catolicismo.

Segundo Lucilene Reginaldo ${ }^{23}$, na construção das identidades de devoções negras a identificação física era o de menos. As compreensões dos símbolos cristãos não se limitavam apenas a aparência exterior das coisas que os negros faziam uso. A partir disso, sugerimos que a prece "Oh meu Deus, ora vamos para o céu", seria utilizada como fonte de poder para a potencialização dos seus credos.

Ao observarmos isso, tendo como base os estudos de James H. Sweet ${ }^{24}$, os símbolos católicos - aqui figurados pela prece descrita - seria a integração desta a visão de mundo africana. Desta forma, não seria a imposição do catolicismo às crenças indígenas da África, mas sim uma reinterpretação do universo religioso europeu. Além disso, não haveria a substituição de uma crença pela outra, mas sim uma conexão entre duas dimensões religiosas que, visivelmente, marcavam suas diferenças em se tratando de como eram postas em práticas. 
Talvez a ritualização africana e a associação ao nzambi mpungu, quando afirmavam que iam para o céu, representassem um aspecto de fronteira entre o animismo e o catolicismo. Por vezes, se atribui aos grupos étnicos uma identidade alicerçada em elementos que não correspondem as suas características reais. Nesse caso, recomenda Barth ${ }^{25}$, para entender essas dinâmicas, é preciso compreender as características que são mais importantes para determinados grupos ou sujeitos. O uso desses aspectos de fronteiras tinha por finalidade potencializar ritos através de outros artifícios religiosos.

A partir do exposto, torna-se possível visualizarmos as adaptações de diferentes identidades étnicas em razão de um interesse pessoal ou coletivo. Como afirma Barth:

\begin{abstract}
Situações de contato social entre pessoas de culturas diferentes também estão implicadas na manutenção da fronteira étnica: grupos étnicos persistem como unidades significativas apenas se implicarem marcadas diferenças no comportamento, isto é, diferenças culturais persistentes. Contudo, onde indivíduos de culturas diferentes interagem, poder-se-ia esperar que tais diferenças se reduzissem, uma vez que a interação simultaneamente requer e cria uma congruência de códigos e valores - melhor dizendo, uma similaridade ou comunidade de cultura. ${ }^{26}$
\end{abstract}

A continuidade de contatos entre diferentes grupos étnicos ocasiona não só aspectos de identificação, mas também a estruturação que possibilita a persistência das diferenças culturais. Amiúde, essas diferenças não implicam superioridade social ou cultural. $\mathrm{O}$ entendimento da fronteira onde os grupos partilham experiências possibilita uma relação de igualdade e benéfica para ambos. A esse respeito, Sweet comenta que muitos acadêmicos objetivam encontrar aspectos cristãos nas manifestações religiosas africanas. Para este autor, esse tipo de tentativa falha ao menos em dois pontos. O primeiro seria que Deus não é uma entidade misteriosa na visão africana, fato comprovado pelas relações ritualísticas empreendidas entre humanos e deuses. O segundo se dá em relação à ausência da ideia de céu e de inferno ${ }^{27}$.

Levando em consideração o que afirmou este autor e desconsiderando a ideia de aspectos sincréticos, cabe questionar: do que se trata, então, o trecho da denúncia? Outra fonte nos sugere que esse tipo de prática era uma forma de ataque aos religiosos. Tomemos como base para nossos argumentos duas coisas: a parte em que "exaltaram os negros com ditérios e cantigas [...] pelas ruas aos ditos missionários" e o trecho de um documento que data de 3 de setembro de 1781, que citamos na íntegra a seguir:

Outra desordem de toda ponderação aconteceu este ano em Varasi aonde fizeram comédia por divertimento - Por intermeio aparecia um [negro] vestido com Hábito 
de Missionários Barbadinhos com barbas e todas as funções de missionários, e com uma carta ia procurando uma mulher que com saia preta manto branco aparecia também ela no teatro, e recebia do Missionário a Carta - O pior é que entregandolhe a carta dava na mulher muitos abraços e beijos, e a tratava com outras maneiras improprias de qualquer não já religioso mas somente homem honrado, e do bem. Quaisquer em Pernambuco tivessem visto tais descomposturas, ou tivessem recebido tão enorme escândalos o que pela graça de Deus não tem acontecido - A segunda noite preparam um púlpito no meio do teatro e um sujeito vestido com hábito, com barbas, e todas as mais funções de Missionários subiu ao púlpito; fez o sinal da Santa Cruz, deu louvores ao Sumo Sacramento, e havia de principiar o Sermão se um zelante clérigo que se achava presente não gritava obrigando ao atrevido deixase daquilo e não passar a maior excesso que daria acabar com batuques e diabrura dos negros. ${ }^{28}$

Consideramos que o teatro ${ }^{29}$ realizado pelos negros tinha mais o sentido de satirizar os religiosos e que em muito se parece com o que fora feito quando saíram às ruas para "escarniarem" os citados missionários, o que demonstra um aspecto da cultura política dos que compunham o teatro. $\mathrm{O}$ uso das barbas, hábitos e outros elementos visuais que caracterizam os Capuchinhos italianos representam uma forma sutil de ataque simbólico contra os mesmos. Acreditamos que essas eram respostas aos ataques feitos contra os batuques, no ano de 1778, e uma denúncia a um Capuchinho em especifico.

Em artigo recente, João José Reis faz algumas considerações sobre o batuque na Bahia no ano de 1785. Para este autor, o batuque representava não somente o campo da religião e crença africana. Este poderia significar um ato subversivo, ou seja, o prenúncio de uma revolta e rebeldia cultural ${ }^{30}$. A afirmação de Reis coincide com o que analisamos sobre os batuques no Recife. Se em dado momento estiveram relacionados à atividade religiosa, por outro lado, também foram utilizados como instrumento político de resistência contra as atitudes dos missionários Capuchinhos.

Ressaltamos que, enquanto para a documentação aqui utilizada o termo batuque gravita entre religião e sátira, para o Rio Grande do Sul, o mesmo caracterizou-se como crença. Nesta região, um dos mitos fundantes do batuque é que teria sido introduzido a partir de uma escrava vinda do Recife. Ali, seria adotado como um sistema de divindades e de regras a serem seguidas ${ }^{31}$. Considerando que o tráfico interno de africanos de Pernambuco para o Rio Grande do Sul só veio a se consolidar após a proibição do tráfico no século XIX ${ }^{32}$, a cultura africana e crioula de Pernambuco, a esta altura, devia apresentar poucas similaridades com os batuques descritos para Recife no século XVIII. Logo, o batuque religioso do Rio Grande do Sul seria diferente dos que analisamos.

A entrega de uma carta para a mulher e, consequentemente, os muitos abraços e beijos não era por acaso. Os protagonistas do teatro estavam a representar padres que, no ato do 
confessionário, propunha atos libidinosos, podendo resultar em toques sexuais e até mesmo a concretização do ato sexual. Destacamos que o objeto representava algo muito conhecido no mundo colonial: cartas de tocar. Quem a portasse, poderia adquirir o amor de quem a tocasse.

A "carta de tocar" 33 era confeccionada para se obter o amor da pessoa que fosse tocada por este objeto.

\begin{abstract}
Bastante utilizado para a conquista amorosa na colônia foram as cartas de tocar, que se tratavam de papelotes ou objetos, tais como ossos, favas, cordas e pedras, por exemplo, onde eram gravados nomes, orações, desenhos místicos ou conjuras demoníacas, e que serviam para atrair a pessoa desejada bastando que se encostasse as ditas cartas no corpo dela ${ }^{34}$.
\end{abstract}

Não obstante, alguns sacerdotes que empreendiam estas práticas eram conhecidos por sua "má fama", como atesta a documentação. A exemplo, no ano de 1783, pesavam acusações contra o padre Capuchinho italiano Frei Mariano da Imola. Segundo carta redigida pelos seus companheiros ${ }^{35}$, o referido religioso tinha "pouca cautela" no falar e no tratar, "principalmente com mulheres". Fora isso, era acusado de, há tempos e em horários impróprios, "frequentar certa casa". Provavelmente a casa de uma mulher. Tendo este exemplo, supomos que o teatro feito pelos negros representava não só o ataque aos Capuchinhos, para além disso, revelava como estavam interligados à sociedade a ponto de saberem e denunciarem - por meio do teatro - práticas que não condiziam com a figura de um religioso. Maneira perspicaz de afrontar aqueles que tentaram moralizar os batuques alguns anos atrás.

A tentativa de se iniciar o sermão do santissímo sacramento, não temos como afirmar se seria realizado por alguma irmandade, se havia alguma profundidade de crença ou se era apenas por diversão. O que podemos evidenciar com certa precisão é que, independente do que fossem essas práticas, elas demonstram o descontentamento dos negros para com os missionários. Além disso, mostra formas de resistências que não se encontram no campo do conflito físico, mas no simbólico.

Se estas pessoas faziam parte de uma irmandade ou não, resaltamos que o sermão nem sempre estava relacionado a conteúdos litúrgicos da Igreja Romana, segundo Julita Scarano ${ }^{36}$. O sermão também era utilizado para tratar de assuntos que eram de interesse comum para o grupo que o iniciasse. Então, não é de se admirar que um clérigo ${ }^{37}$ tenha evitado o início do mesmo, provavelmente prevendo que aqueles negros do teatro colocariam em pauta a repressão que sofriam por parte dos Capuchinhos. 
Paulo Sicato Chitunda apresentou outro dado importante sobre a dinâmica dos cultos nas Irmandades, em especial, a do Rosário de Olinda, "que no dia da festa em homenagem a Nossa Senhora do Rosário, a missa que seria pela manhã deveria ser preenchida por "sermão" e música, redundando em uma "missa cantada",38. Caso os negros realizassem o teatro em uma irmandade, o que levaria um clérigo a ter tanta autoridade a ponto de impedir de se iniciar um sermão? Estaria ordenado pelos missionários Capuchinhos? Em caso afirmativo, será que o Bispo sabia ou concordava?

Apesar de não ter vindo a público, "tudo isso ocorreu na presença de um ministro de Sua Majestade o Juiz de fora", João da Silveira Pinto Nogueira. Após o ocorrido, o então Prefeito das missões, Constantino de Parma, o mesmo que se empenhou na quebra dos instrumentos e na perseguição aos batuques, recorreu ao Bispo D. Tomás da Encarnação Costa e Lima, o qual, por sua vez, o encaminhou para o Governador, e este, por fim, o mandou recorrer ao Juiz de Fora. "E tudo quanto fizeram contra dos criminosos foi uma pura aparência, e por exterior demonstração",39.

Segundo Constantino de Parma, a "exterior demonstração" contra os negros fora feita em comum acordo entre o Bispo e o Governador e Capitão General. Consta que os mesmos se sentiam ofendidos, o primeiro, por ter a sua função de Bispo contestada pelo Prefeito, pois permitia que "moços e moças dançassem escandalosamente", e era em excesso amigo do dito Governador que se achava ofendido "pela proibição dos batuques". Vejamos a seguir como ocorreu essa proibição e quais motivos levaram o Prefeito a fazer tal afirmação.

\section{"Desordens contrárias à fé e à religião": os batuques e a permissividade do governo de Pernambuco}

Tentaremos expor, a partir da documentação do Arquivo Histórico Ultramarino, como se deu início a um embate entre a administração secular e a ordem missionária dos Capuchinhos. Deixamos claro que, especialmente nesta seção, o fato de deslocarmos nossas análises para o Governador e para os religiosos não significa dizer que estão separados das dinâmicas e vivências africanas na Capitania de Pernambuco.

Como assinalado anteriormente, haviam chegado à Pernambuco, especificamente no Recife, quatro missionários Capuchinhos italianos ${ }^{40}$, com permissão real da Rainha D. Maria I e ciência do Governador da mesma Capitania. Aparentemente essa seria mais uma remessa de missionários que, comumente, vinham ao Brasil para cuidar das almas e o bom funcionamento da religião e da fé católica. A chegada dos missionários, no ano de 1778, 
compõe um quadro complexo que deu início a vários conflitos entre os súditos ultramarinos que estavam envolvidos com a administração das possessões de Portugal. Tal ano marca não só o desembarque de quatro fervorosos religiososb, mas também o início de uma disputa de poder desencadeada pela prática da cultura africana.

Após a denúncia feita pelo religioso Domingos de Oliveira, o Santo Ofício enviou uma carta para o Governador de Pernambuco comentando sua suposta proteção aos "pretos católicos naturais do gentio de Angola, e com especialidade os da Costa, que usando de danças acompanhadas dos ritos e cerimonias gentílicas" ${ }^{41}$, as executam em praça e é do conhecimento público. Adiante, segue parte da carta:

\begin{abstract}
E determinando nós [...] que se desterre um costume [que] não respira mais que superstição, idolatria e dissolução tão pouco admirável e disfarçável, quanto digna da mais pronta estranheza [...] pelo que animados com os esforços que nos promete a nossa bem fundada esperança, requeremos a V. Ex. ${ }^{a}$. da parte da mesma Santa Igreja [...] por obsequio da fé Católica, que felizmente professa aplicar todos os meios que a sua iluminada, e religiosa prudência lhe ditar, para se erradicar de uma vez aquele tão depravado e abominável costume, decretando V. Ex.. ${ }^{a}$. como Governador e Capitão General desse Estado as ordens, que julgar convenientes para se conseguir, e auxiliando com a sua respeitável proteção aos Missionários, que publicamente repreendem, e detestarem, para mais vivamente se conceberem os delinquentes o horror que merece sua culpa.
\end{abstract}

Como podemos observar na carta escrita pelo Santo Ofício, alguns aspectos da denúncia feita por Domingos foram tomados como verdade, fato esse que se comprova no pedido de sua "respeitável proteção aos missionários", e, ao que tudo indica, tomaram a decisão destes de saírem às ruas e destruírem os instrumentos como correta, pois reconhecem "que publicamente repreendem abomináveis costumes" supostamente defendidos pelo Governador.

Em seguida, a carta foi respondida pelo Governador ao Tribunal e à Rainha, justificando que a penalização feita aos missionários era justa, pois os referidos clérigos deviam utilizar a razão ao invés de violência para a conversão dos não-cristãos, assim como não poderia permitir que se usasse a força em detrimento da persuasão. A carta segue dizendo:

Porém como a recomendação de Vossa Excelência me parece fundada em notícias que se não verificam devo dizer a Vossa Excelência que é custoso proibir o divertimento de uns homens penosamente trabalhados conservam nas tais danças dos seus Ritos Gentílicos como falsamente se representou a V. Ex. ${ }^{a}$, pois não é verossímil que estando aqui um Bispo, tantos Párocos, e Prelados, e tantos Missionários com tantos antecessores meus, nenhum deles achasse razão para se proibirem tais danças antes se fecha os olhos a isso por uma razão de Estado; por que uns homens constituídos em um cativeiro pesado desesperançado se não 
tivessem no domingo aquele divertimento e se lançariam a distúrbios mais sensíveis se lhes não permitissem, como sucedeu nos tempos antigos a um dos meus antecessores que o quis proibir não por que usassem nas danças dos ritos que falsamente se lhe acumulam, mas só pelo barulho e algazarra que fazem; e estas danças as fazem fora desta Praça junto aos seus arrabaldes ${ }^{42}$.

Até esse ponto são evidentes as razões do Governador ter afirmado que as notícias são fundadas em mentiras. A princípio, é possível entender que faça menção apenas a duas versões relatadas sobre o episódio dos batuques, mas nossas pesquisas apontaram para algo delicado, que envolve tensões entre o poder do Governador e o Prefeito das missões, Constantino de Parma. Sobre a sua permissão aos batuques, afirma José César que se trata de uma "razão de Estado", pois, antes, fecharam os olhos para isso, a fim de evitar males maiores, como um levante por parte dos escravos.

Para Mônica da Silva Ribeiro, o conceito de "razão de Estado" foi discutido pelos humanistas desde o século XIV. Para a autora, significa "o surgimento de uma nova cultura política na forma de administrar e governar os territórios [do império português] na virada do século XVII para o XVIII"43. Essa prática que surgiu no início da Idade Moderna tinha como máxima que os fins justificavam os meios. No caso de Pernambuco, a permissão e aceitação dos batuques parecem estar em comum acordo com esse pensamento.

É possível entender que o modo como a população negra de Pernambuco vivia era muito diferente de como objetivava o clero religioso. Sendo assim, seria

Bem claro que o soberano [no nosso caso, o Governador José César de Meneses] não deve se importar em praticar vícios que o auxilie na manutenção do Estado, porque, segundo ele [Maquiavel], certas qualidades que parecem virtudes levam à ruína, enquanto outras que parecem vícios trazem o aumento da segurança e do bemestar $^{44}$.

José César de Meneses, se tinha conhecimento ou não da obra de Maquiavel ${ }^{45}$, levava a cabo a ideia de ceder a certos "vícios" em troca da boa manutenção do Estado. Mesmo que não fosse visto com bons olhos pela Igreja Romana, era preferível ter sua reputação questionada do que levar a Capitania a distúrbios delicados na sua administração, fato esse que ele explicita ser impróprio proibir "divertimentos" para não correr o risco de levante por parte dos escravos.

Também é preciso levar-se em conta que as sociedades das diversas partes do império, mais precisamente a da América portuguesa no século XVIII, não eram uma reprodução fiel e exata daquelas dos séculos anteriores, embora a dinâmica política continuasse impregnada das mesmas práticas e culturas políticas, em que valores como amor, amizade, afeto, fidelidade, obrigações, acrescentamentos, concessões, ainda persistiriam durante muito tempo nas relações entre monarca e vassalos ${ }^{46}$. 
A crescente preocupação por parte de Portugal para com suas possessões ultramarinas provocou o surgimento de novas estratégias de governo, buscando uma maior racionalidade em todos os setores administrativos. Silva afirma que o "Brasil tornou-se um dos principais palcos de implementação dessa nova "razão de Estado", consubstanciando-se, assim, em espaço privilegiado para o surgimento de uma nova cultura política"47.

Essa racionalização não ficava apenas no plano das finanças, controles de físco, fazenda e outros elementos de natureza administrativa, passava também pela vida dos colonos e interferia no projeto político das ordens religiosas, que representavam a tentativa de moldar o cotidiano da colônia aos interesses religiosos da Igreja de Roma. Sendo assim, o conceito utilizado pelo Governador demonstra uma complexidade "de pluralidade de culturas políticas inscritas nas variadas práticas e representações existentes"48 na Capitania de Pernambuco em finais do século XVIII.

D. Tomás da Encarnação Costa e Lima (1774 - 1784), Bispo em exercício neste período, parecia também partilhar da política de ceder para a boa paz dos domínios portugueses. Este recebera recomendações em 4 de julho de 1780, do ministro da marinha e ultramar, Martinho de Mello e Castro, sobre o que deveria agir em conjunto com José César para erradicarem as danças dos pretos. ${ }^{49}$ Em 28 de Setembro do mesmo ano, D. Tomás encaminha um ofício para o mesmo Secretário sobre o seu posicionamento a respeito destas danças. O Bispo afirmava que "as danças dos pretos, chamadas batuques, ainda que fossem sempre toleradas nestas conquistas, com tudo sempre as julguei gentílicas, contrarias ao sossego público" ${ }^{50}$, mas que apesar de serem toleradas, a "boa paz do sacerdócio e do império" eram de suas maiores considerações, e que, por isso, destinava-se a cooperar com o dito Governador para os fins indicados de erradicar tais costumes dos pretos de dançarem.

Agora S. Maj. manda, e eu da minha parte cooperarei não só a respeito destas, mas também devemos bem contrarias a lei de Deus e aos bons costumes, como sejam umas na festividade de S. Gonçalo de noite tumultuosas umas mulheres com tambores, e alaridos, de um e outro sexo pelas ruas contra as quais tenho clamado e mandado clamar dos pupilos até fechar as mesmas igrejas de noite para se evitarem as desordens ${ }^{51}$.

As palavras do Bispo nos fazem uma revelação bastante útil e que provavelmente podem nos ajudar a propor novas questões. Atentamos ao fato de que em momento algum as denúncias falaram do envolvimento de irmandades, mas sim de escravizados e livres que 
praticavam ritos e batuques em praça pública. Sendo assim, quais razões levaram o Bispo a se deslocar do assunto principal e tratar das irmandades como se estas fossem o problema?

Amplamente difundida na historiografia, as irmandades eram grupos formados no seio das comunidades escravas, sendo compostas por africanos, seus descendentes e outros grupos como os brancos e pardos. Não obstante, estas eram reconhecidas e autorizadas pelas autoridades leigas do Brasil Colonial e da Metrópole. Mesmo que fossem festividades “tumultuosas”, como a de São Gonçalo, ainda que reprovadas pela Igreja, eram aceitas pela população e setores políticos da época.

As festas propostas pelas irmandades de negros, pardos, brancos, entre outros, tinham como uma de suas finalidades a devoção. Nesses espaços, o campo do sagrado misturava-se ao folgar, ao lazer, às danças, aos batuques e a outras expressões dos povos de matriz africana e afro-brasileira. Chitunda aponta em seu estudo que essas festas também representavam a manutenção dos símbolos ancestrais banto, ou seja, a formação destas irmandades teria no seu seio uma composição maciça de centro-africanos ${ }^{52}$, e supõe ainda que os batuques, alvos das denúncias aqui apresentadas, eram realizados principalmente nas festividades das Irmandades, afirmando que estes costumes eram em especial realizados pelos angolanos.

$\mathrm{Na}$ primeira metade do século XX, Edison Carneiro abordava o batuque de origem angolana em uma perspectiva cultural. Para este autor, o batuque conhecido atualmente, e que em muito se assemelham aos aqui analisados, eram de procedencia banto. Logo, concordamos com a sua visão e a de Chitunda, no que se refere a origem destes costumes.

Quando a Mesa da Inquisição endereçou a carta para o Governador de Pernambuco deixa bem claro que Angolanos e Minas realizavam tais atos, mas atesta que "com especialidade os da Costa [da Mina]" empreendem rituais mais específicos. O parecer do Conde de Povolide, nesse caso, nos parece bastante útil para entendermos esse trecho. Como descrito, ele informa que havia duas formas de dançar: as que pareciam com lunduns e as que os pretos Mina realizavam as escondidas sobre um altar e adorando seus ídolos. Essa informação nos leva a crer, sem generalizações, que havia uma divisão étnica dos costumes empregados por ambos os grupos. Enquanto centro-africanos pediam esmolas pelas ruas e dançavam, os Minas faziam rituais mais específicos envolvendo costumes e crenças não condizentes com os ideais católicos.

Apesar dessa divisão visível entre os grupos, que, diga-se de passagem, notamos também na composição de cargos das irmandades ${ }^{53}$, sugerimos que ambos os grupos também participassem das cerimônias, sejam elas na perspectiva de um catolicismo africanizado (ou 
um animismo com elementos católicos), sejam de rituais animistas. Nos parece que batuque estava ligado a mais de um entendimento. Para Laura de Mello e Souza, baseada em Câmara Cascudo, o lundu que nos fala o Conde foi o pai do fado português por ser cantado. "No Norte e no Nordeste do Brasil, dançava-se o fado sob o nome de lundu; com o tempo, este acabou convergindo para batuque, que era angolano, considerado "dança indecente" ${ }^{54}$. Viajantes na África Ocidental e oriental designaram o batuque tanto pela sua percussão quanto pela sua coreografia, sempre feita em roda para dançar ${ }^{55}$.

Apesar de se entender o batuque como elemento da cultura banto, surge um novo problema: o batuque era realizado apenas por angolanos? Yeda Pessoa de Castro associa lundu a Calundu ${ }^{56}$, este último é uma agremiação de práticas ritualísticas de origem centroafricana, mas que em muito assemelha-se a práticas realizadas por africanos da Costa da Mina. Seria o batuque comum a ambos? Teriam Minas e Angolas especificidades compartilhadas no campo religioso?

Qual a importância de frisar a polissemia desta palavra? Se remetermos ao contexto em que ela foi inserida, iremos descobrir que se tratava de um jogo de palavras utilizado por duas instâncias administrativas do Brasil Colonial: o Governador de Pernambuco e o Santo Ofício. O primeiro, tomava para si o termo batuque como simples algazarras e divertimentos; o segundo, entendia que a palavra estava ligada a rituais "gentílicos". Ou seja, se admitia um ou outro significado da palavra com o objetivo de atender aos interesses de quem estava inserido no caso. Em outras palavras, essa divisão era perceptível aos que apenas observavam e, além disso, eram usadas de acordo com os seus interesses.

O fato de falarmos isso serve para entendermos os motivos do Bispo D. Tomás chamar a atenção para este assunto, quando o que interessava naquele momento era a erradicação dos batuques, que, ainda que fossem realizados nas festividades, não ocorriam com frequência, pois possuíam calendários específicos para as suas solenidades. $\mathrm{O}$ que podemos deduzir de sua afirmação é que o seu "silêncio", em relação aos batuques, corrobora com o que Constantino dizia em 1781, "que o Bispo é amigo em excesso do General”. Mesmo que tais motivos fossem de sua total reprovação, como o mesmo afirmava, parecia que o Bispo partilhava a mesma visão do Governador, ou seja, "fecha-se os olhos a isso por uma razão de Estado".

O tom conciliador de José César de Meneses, a aceitação do Bispo (mesmo dizendo o contrário) e o constante embate entre a esfera religiosa e administrativa sobre as expressões africanas e afro-brasileiras revelam interesses distintos. Para a Igreja, a tentativa de usar a 
Inquisição para barrar esses costumes demonstra o interesse de normatizar os africanos batizados na vivência católica; para o Governador e o Bispo, a aceitação destas práticas era fundamental para o bom funcionamento da Capitania.

\section{Caminhando para um desfecho? A decisão de D. Maria I}

Como percebemos, havia um embate entre as esferas administrativas em Pernambuco no fim do século XVIII. Acusações iam e voltavam, e muitas atitudes repressivas e permissivas eram tomadas. Enquanto isso, os atores principais desta trama, os escravos, davam continuidade as suas expressões culturais, missas para os "parentes ou malungos", divertiam-se nas festividades das irmandades, e brincavam nos domingos e dias santos. Não havendo mais sustentação argumentativa de ambos os lados, a figura da Rainha se fez presente para a tentativa de solução do caso dos batuques. Em 10 de Junho de 1780, fora pedido ao Conde de Povolide, Luís José da Cunha Grão e Ataíde, ex-Governador da Capitania de Pernambuco (1768-1769) e Bahia (1769-1774), que desse um parecer sobre as danças descritas tanto pelos missionários quanto as que descreveu José César de Meneses.

Atendendo ao pedido real, o conde descreve que as danças eram realizadas por pretos que se dividiam em nações, cada uma com instrumentos próprios, dançavam e faziam voltas como arlequins, e outros com diversos movimentos que "são como os fandangos de Castela, e fofas de Portugal, e os Lundus dos Brancos e Pardos daquele País [Brasil]" não fossem inocentes, eram parcialmente aceitas. Para o conde, as danças que o Governador falava eram estas. Quanto às que a Inquisição e os missionários falavam, eram as que

Entendo ser de uma total reprovação, são aqueles que os pretos da Costa da Mina, fazem às escondidas, ou em Casas, ou Roças, com uma Preta Mestra, com Altar de Ídolos, adorando Bodes vivos, e outros feitos de barro, untando seus corpos com diversos óleos, sangue de galo, dando a comer bolos de milho depois de diversas benções supersticiosas, e fazendo crer a Rústicos, que naquelas unções de pão dão fortuna, e fazem querer bem Mulheres a Homens, e Homens a Mulheres ${ }^{58}$.

A descrição feita sobre o segundo tipo de dança que o mesmo vira em Pernambuco coincidia com as denunciadas ao Tribunal do Santo Ofício. Aqui surge um novo elemento até então não mencionado nas denúncias. Anteriormente, falou-se dos batuques com certa ausência de aspectos mais específicos da religiosidade negra, mas aqui eles figuram-se com mais ênfase, o que possibilita uma análise mais profunda do panorama destas danças fortemente repreendidas. 
Há uma certa homogeneização daqueles que praticavam tais danças quando, na documentação, é evidente que havia uma divisão entre os grupos que faziam parte dos batuques e danças. No primeiro momento, evidenciou-se que angolanos empreendiam atos considerados "torpes" com elementos católicos; agora, em segundo plano, o Conde de Povolide afirmava que os africanos provenientes da Costa da Mina realizavam cerimônias mais parecidas com as da África.

Esse é um dado importante para que possamos entender a própria configuração desses espaços festivos e religiosos criados pelos negros do Recife no século XVIII. Em se tratando de vivência religiosa, ambos os grupos, Angolas e Mina, possuíam características específicas determinadas pela geografia local que ocupavam na África e, ao que tudo indicava, parece ter sido transportada para Pernambuco, claro que, adaptadas de acordo com o ambiente em que foram inseridas.

A importância de se compreender a "procedência" destes grupos descritos na documentação nos ajuda a entender como se formou essa divisão de práticas expostas nas denúncias a partir da diversidade de organização das "nações africanas". Reforçamos que, apesar da ideia de que os grupos tenham, de certa forma, mantido representações de suas vidas anteriores a escravização, "nenhum grupo, por mais bem equipado que esteja, ou por maior que seja a sua liberdade de escolha, é capaz de transferir de um local para o outro, intactos, seu estilo de vida"59.

Estes rituais "chega a tanto a credulidade de algumas pessoas, ainda daquelas que não pareciam serem tão rústicas, como Frades e Clérigos", que estes acabavam por se incorporarem às cerimônias dos negros. Comenta o conde que muitos religiosos chegaram presos a sua presença denunciados pelos "cercos que mandava botar a estas Casas, que querendo-os desmaginar", posteriormente, remetidos aos seus prelados para serem corrigidos, "e os negros fazia castigar com rigorosos açoites, e obrigava aos senhores que os vendessem para fora: Estas são as duas Castas de Bailes, que vi naquela Capitania em o tempo que a Governei". 60

Não era novidade que religiosos se envolvessem em cerimônias "gentílicas". Ao menos dois casos podem ilustrar bem este tipo de ocorrência. A primeira data da segunda metade do século XVII, e a segunda, do ano de 1781. Nos diz o Capuchinho Cavazzi que muitos missionários, na África, às vezes, queriam usar de juramentos e bebidas que aprendiam com os feiticeiros para terem a verdade sobre algum fato ou objeto desaparecido ${ }^{61}$. Nosso já conhecido missionário Constantino denunciava que o Bispo de Pernambuco, D. 
Tomás da Encarnação Costa e Lima, permitia escândalos dentro de sua igreja, onde moços e moças dançavam escandalosamente ${ }^{62}$.

Voltando aos batuques, após o parecer elaborado pelo Conde de Povolide, D. Maria I decide advogar em defesa dos missionários Capuchinhos e acata que a melhor forma de solucionar o caso é proibindo os batuques. Em 3 de Outubro de 1780, José César de Meneses novamente endereçava uma carta para a Rainha D. Maria I, em que constava:

Fico na inteligência do que V. Majestade é servida ordena-me na carta de V. Ex. ${ }^{a}$ datada em quatro de julho do corrente ano a respeito das danças que os pretos costumam fazer nesta Capitania, e daqui por diante darei todas as providências que achar mais convincentes para ir desterrando pouco a pouco este divertimento tão contrário aos bons costumes ${ }^{63}$.

Desterrar "pouco a pouco" era a forma encontrada pelo Governador para manter a livre manifestação dos negros. Vários fatores foram descritos que o levavam a ter essa posição frente aos festejos africanos, medo de levantes e, quem sabe, não visse nos batuques nada que se conservasse "gentílico". Do ponto de vista da Rainha, sua ordem não poderia ser diferente da que foi emitida. A sustentação contra os batuques transmitia a ideia de um império centralizado e que, em última instância, vigorava a palavra real. Provavelmente, para D. Maria I, “defender o contrário disso, isto é, destacar o papel constitutivo de elementos periféricos, seria contra produtivo e permitiria o enfraquecimento" ${ }^{\prime 64}$ do poder monárquico frente às expressões culturais africanas.

O Governador de Pernambuco tinha ciência da situação. A ordem movida pela Rainha, independente de motivos religiosos ou não, poderia ser facilmente contornada mediante o poder que um Governador detinha. Antônio Manuel Hespanha ${ }^{65}$ demonstra que os governadores ultramarinos detinham uma série de poderes, dentre os quais, poderiam, mediante circunstâncias específicas, não acatar ordens reais ou tomar decisões sem aviso prévio a coroa. O último quartel do século XVIII, na Capitania de Pernambuco, foi palco de um forte embate entre administração colonial e religiosa. Os protagonistas eram: escravos negros, um Governador, missionários e um Tribunal religioso. Todas as atitudes empregadas nesses episódios decorreram de vontades individuais, porém, instaladas em uma sociedade instável com uma variação étnica complexa sujeita as amarras e turbulências do cativeiro.

Em maior ou menor grau, os escravos livres e libertos atuaram como figuras principais no processo de disputa de poderes e afirmações perante as autoridades eclesiásticas e seculares. As contendas que surgiram durante o período em que as denúncias analisadas foram escritas nos revelam sempre a participação dos africanos de forma direta ou indireta. 
Ainda que estes sujeitos, em muitos casos, sejam referenciados de forma indireta, conseguimos acompanhar os seus protagonismos representados na fala de personagens como Constantino de Parma e José César de Meneses, que, durante todo o entrave que estabeleceram sobre o caso dos batuques, deram visibilidade às ditas manifestações culturais empreendidas pelos africanos e pelos seus descendentes.

\section{NOTAS}

${ }^{1}$ Os documentos referentes ao Conselho Ultramarino foram digitalizados pelo Projeto Resgate Barão do Rio Branco, sob a coordenação de Esther Caldas Bertoletti. O referido projeto reuniu pesquisadores do Brasil e de outros países da Europa. Foram organizados e catalogados, por período e região, milhares de documentos respeitantes ao século XVI ao XIX. Aqui, utilizamos a coleção relativa à capitania de Pernambuco. Para saber mais sobre o projeto, ver: BERTOLETTI, Esther Caldas.; BELLOTO, Heloisa Liberalli.; DIAS, Erika Simone de Almeida. O projeto resgate de documentação histórica Barão do Rio Branco: acesso às fontes da história do brasil existentes no exterior. Clio - revista de pesquisa histórica, n. 29.1 (2011).

${ }^{2}$ Os processos movidos pelo Tribunal inquisitorial de Lisboa são compostos por folha de abertura (onde contém o sumário de culpa ou denúncia e o nome do réu); segue-se com a explicação do caso; perguntas a testemunhas e ao réu; e, por fim, a sentença e os custos do processo. Cabe salientar que nem todos os processos movidos pela Inquisição eram concluídos. Muitos destes estão ausentes de sentenças e de perguntas às testemunhas. $\mathrm{O}$ segundo tipo de documento utilizado nesta pesquisa, também de origem inquisitorial, está nos chamados "Cadernos do Promotor". Nestes cadernos, encontram-se denúncias que poderiam originar os processos descritos acima. Não há uma organização por capitanias nestes cadernos, respeitando apenas a ordem cronológica de produção das denúncias. Estão dispostos em 139 volumes que cobrem o período de 1541 a 1802. Na coleção de "Cadernos do Promotor", existe uma série intitulada de "Papéis de Fora" ou "Papéis Antigos", que vão de 1565 a 1587. Estes papéis encontram-se de forma desordenada e com lapsos de numeração. Em geral, todos os volumes contêm denúncias referentes à Lisboa, à África, ao Brasil e à Índia. As denúncias variam seu número de páginas, a depender do denunciante e da gravidade do suposto crime. Por fim: "Existem vários lapsos da numeração original, tratando-se os mais frequentes de repetições e saltos: o caderno 3..$^{\circ}$ de "Papéis de Fora" ou "Papéis Antigos", aparecem duas vezes; os cadernos $10 .^{\circ}$ a $13 .^{\circ}$ dos "Papéis de Fora" ou "Papéis Antigos" não foram ainda encontrados, assim como os cadernos $25 .^{\circ}, 42 .^{\circ}, 43 .^{\circ}, 62 .^{\circ}, 63 .^{\circ}, 65 .^{\circ}, 78 .^{\circ}, 103 .^{\circ}, 123 .^{\circ}$, 127..$^{\circ}$ 132..$^{\circ}$ e $\quad$ o $135 .^{\circ}$ dos séculos XVII a XIX". Ver: <http://digitarq.dgarq.gov.pt/DetailsForm.aspx?id=2318017>. Acesso em 06/04/2017.

${ }^{3}$ Os outros onze eram: Fr. Izidoro de Vignale, Fr. Raymundo de Veneza, Fr. Clemente de Andorno e Fr. Gelazio de Moreta tiveram como destino a Capitania da Bahia; Fr. Antônio Maria de Veneza (foi como Prefeito da missão), Fr. Pedro de Veneza, Fr. Victorio de Cambiasca e Fr. Salvador Mãe de Vercelle foram servir missão no Rio de Janeiro; Fr. Lucas de Rouabranca e Fr. Boaventura de Veneza (foi como Prefeito) foram enviados para São Tomé; e Fr. Bernardino Podevaninho para Angola. Por motivos de saúde. Fr. Luigoi da Sena não foi enviado como missionário ao Congo. Rol dos Missionários Barbudinhos Italianos Vindos de diferentes Províncias de Itália para as Missões das Reais Conquistas de Sua Majestade Fidelíssima. Laboratório de Pesquisa e Ensino de História (LAPEH). Arquivo Histórico Ultramarino, CU-Diversos, Cx. 6, D. 476.

${ }^{4}$ Laboratório de Pesquisa e Ensino de História (LAPEH). Arquivo Histórico Ultramarino, Códice 583, fls. 190v191. O mesmo documento também pode ser encontrado na coleção de avulsos sobre a Capitania de Pernambuco, Cx. 130, D. 9816.

${ }^{5}$ Arquivo Nacional da Torre do Tombo, Processo no 4740.

${ }^{6}$ SILVA, Kalina Vanderlei. O teatro urbano - sociabilidades urbanas açucareiras em Pernambuco nos séculos XVII e XVIII. CLIO: Revista de Pesquisa Histórica, n. 29.2 (2011).

${ }^{7}$ A documentação nos leva a entender que a licença dada aos cativos e libertos foi concedida mediante a censura dos missionários capuchinhos. Não encontramos um momento específico, e o único documento que faz menção direta a este ato do governador é a denúncia arquivada na Torre do Tombo (Processo $\mathrm{n}^{\circ}$ 4740). Para fins cronológico, no ano de 1778 começa os conflitos entre os africanos, capuchinhos e José César de Meneses. 
Entre finais de 1778 e início de 1779, ocorre a denúncia supracitada e, em 1780, o governador responde as supostas acusações enviando cópia de sua carta para o Conselho Ultramarino.

${ }^{8}$ Arquivo Nacional da Torre do Tombo, Processo $n^{\circ} 4740$.

${ }^{9}$ Laboratório de Pesquisa e Ensino de História (LAPEH). Arquivo Histórico Ultramarino, Pernambuco, Cx. 135, D. 10140.

${ }^{10}$ Basicamente as fontes utilizadas sobre o caso em questão é o parecer do Conde de Povolide e denúncia contra José César de Meneses. Aqui, além de acrescentarmos os documentos relativos a Inquisição, analisamos, também, os conflitos que surgiram a partir dos embates entre a administração colonial e os capuchinhos italianos.

${ }^{11}$ MELLO, José Antônio Gonsalves de. Um Governador colonial e as seitas africanas. Diário de Pernambuco. Recife, 22 Jan. 1950.

${ }^{12}$ ARAÚJO, Rita Cássia B. de. Cruzes, plumas e batuques: festas públicas e colonização na América portuguesa. Ci. \& Tróp. Recife, v. n. 2, p. 161-181. Jul/Dez, 2000. p. 178.

${ }^{13}$ SILVA, Luiz Geraldo. "Da festa barroca à intolerância ilustrada: Irmandades católicas e religiosidade negra na América portuguesa (1750-1815)". In: SALLES-REESE, Verónica (Org.). Repensando el pasado, recuperando el futuro: nuevos aportes interdisciplinarios para el estúdio de la América colonial. Bogotá: Editorial Pontifcia Universidad Javeriana, p. 313-335.

${ }_{14}$ Arquivo Nacional da Torre do Tombo, Processo no 4740.

15 Idem.

${ }^{16}$ Idem.

17 SWEET, 2007, p. 128.

${ }^{18}$ SLENES, Robert W. "Malungu, ngoma vem!": África coberta e descoberta do Brasil. In: Cadernos do Museu da Escravatura, n. 1. Ministério da Cultura. Luanda, 1995.

${ }^{19}$ MELLO E SOUZA, Marina de. Reis negros no Brasil escravista. História da festa de coroação de Rei Congo. Belo Horizonte, Editora da Universidade de Minas Gerais, 2002, p. 260.

${ }^{20}$ CAVAZZI, João Antônio de Montecúccolo. Descrição histórica dos três reinos do Congo, Matamba e Angola. Junta de Investigação do Ultramar. Lisboa. 1965, p. 87.

${ }^{21}$ Existem outros deuses com denominações parecidas: Nzambi-caca (único Deus); Nzambi-a-diulu (Deus do céu). CAVAZZI, João Antônio de Montecúccolo. Descrição histórica dos três reinos do Congo, Matamba e Angola. Junta de Investigação do Ultramar. Lisboa. 1965, p. 88.

${ }^{22}$ Arquivo Nacional da Torre do Tombo, Processo $n^{\circ} 4740$.

${ }^{23}$ REGINALDO, Lucilene. Os rosários dos angolas: irmandades de africanos e crioulos na Bahia setecentista. São Paulo: Alameda, 2011, p. 39-40.

24 SWEET, 2007.

${ }^{25}$ SWETT, 2007, 196.

${ }^{26}$ BARTH, Fredrik. Grupos étnicos e suas fronteiras, In: POUTIGNAT, Philippe e STREIFF-FNART, Jocelyne. Teorias da etnicidade. São Paulo: UNESP, 1998, p. 196.

${ }^{27}$ SWEET, 2007, p. 132.

${ }^{28}$ Laboratório de Pesquisa e Ensino de História (LAPEH). Arquivo Histórico Ultramarino. Pernambuco, Cx. 141, D. 10415 .

${ }^{29}$ No século XVI, na Europa, o teatro não era visto com bons olhos. Católicos e protestantes, que ficaram conhecidos como "reformadores da cultura popular", combatiam e censuravam este tipo de atividade. Apesar do teatro, neste período, estar ligado às camadas mais abastadas da sociedade europeia, ainda assim, era considerada "liturgia do Diabo". Para uma discussão a respeito da cultura popular na Europa, ver: BURKE, Peter. Cultura popular na idade moderna. Europa, 1500-1800. São Paulo, Companhia das Letras, 1989. Sobre o teatro no Brasil, ver: MAYOR, Mariana Soutto. O teatro do século XVIII no Brasil: das festas públicas às casas de ópera. Revista aSPAs. Vol. 5. n. 2. 2015, p. 104-110; TOLEDO, Cézar de Alencar Arnaut de; RUCKSTADTER, Flávio Massami Martins; RUCKSTADTER, Vanessa Campos Mariano. O teatro jesuítico na Europa e no Brasil no século XVI. Revista HISTEDBR On-line, Campinas, n.25, mar. 2007, p. 33-43.

${ }^{30}$ REIS, João José. Revisitando "Magia jeje na Bahia”. In: COSTA, Valéria Gomes.; GOMES, Flávio. Religiões negras no Brasil: da escravidão à pós-emancipação. Editora: Selo Negro, 2016, p. 22.; REIS, João José. Batuque Negro: repressão e permissão na Bahia oitocentista. In: JANCSÓ, István; KANTOR, Iris (Orgs.). Festa: cultura e sociabilidade na América Portuguesa. São Paulo: Hucitec, 2001, p. 339-358.

${ }^{31}$ ORO, Ari. Religiões Afro-Brasileiras do Rio Grande do Sul: passado e presente. Estudos Afro-Asiáticos, Ano $24, \mathrm{n}^{\mathrm{o}}$ 2, 2002, pp. 345-384. 
${ }^{32}$ BERUTE, Gabriel Santos. O tráfico negreiro no Rio Grande do Sul e as conjunturas do tráfico Atlântico. C. 1790 - c. $1830.5^{\circ}$ Encontro Escravidão e Liberdade no Brasil Meridional. 2012, p. 15.

${ }^{33}$ Não existe um texto padrão para essas cartas. Seu conteúdo varia de acordo com quem a escreve. Além do texto, pode haver a presença de materiais considerados sagrados, como hóstia e pedra d'ara. A seguir, dois exemplos de simpatias utilizadas na colônia: "Com dois te vejo, com cinco te prendo, o coração te parto o sangue te bebo; quando me vires, por mim suspires, e quando me vires a mim te arrimes pela lenha da Vera Cruz para sempre. Amém Jesus". Ver mais em: Arquivo Nacional da Torre do Tombo. Caderno do Promotor no 124. Além das cartas, outros rituais (feitiçaria para a Inquisição) eram utilizados para fins amorosos. Em Pernambuco, no ano de 1718, Ana Monteiro, parte de cristã-nova, e de 30 anos de idade, realizava simpatias para várias pessoas em Recife. Em processo aberto pela Inquisição de Lisboa, parte desta prática foi registrada: "Neste portal me venho assentar, e não vejo fulano, nem tenho, que lho buscar: vá Barrabás, vá Satanás, vá Lúcifer, vá sua mulher Maria Padilha com toda a sua quadrilha, e todos se queiram juntar, e em casa de fulano entrar, e o não deixem comer, dormir, nem repousar, sem que pela minha porta dentro venha entrar". Ver: Arquivo Nacional da Torre do Tombo. Processo 1377-1. p. 248.

${ }^{34}$ VALE, Fernanda Cristina. Linguagens de amor: a feitiçaria como meio de conquista amorosa no Brasil colonial. III Seminário Linguagem e Identidades: múltiplos olhares. p. 8.

${ }^{35} \mathrm{~A}$ folha de abertura do ofício encontra-se com fortes vazamentos de tinta nas assinaturas, que, ao todo, são sete. Dentre elas, identificamos: Frei João Baptista; Frei Valência; Frei Vidal; Frei Joaquim; Frei Pedro Lourenço de Loussalo. A redação do documento foi feita pelo Frei Clemente de Moreta, vice-prefeito [do convento] da Penha. Ver mais em: Laboratório de Pesquisa e Ensino de História (LAPEH). Arquivo Histórico Ultramarino, Pernambuco, Cx. 148, D. 10763.

${ }^{36}$ SCARANO apud CHITUNDA, Paulo Alexandre Sicato. Entre missas e batuques: Irmandade Nossa Senhora do Rosário dos Homens Pretos em Recife, Goiana e Olinda - Século XVIII. Dissertação de Mestrado apresentado ao PPGH- UFRN. Natal, 2014, p. 170-171.

${ }^{37}$ Outra possível explicação para esta situação pode ser dada através de uma Pastoral escrita pelo bispo de Pernambuco, D. Tomás, em 13 de setembro de 1774. Em uma circular impressa destinada "ao clero, e povo de Pernambuco", pedia o bispo que "todos os párocos da nossa Diocese, não administrem o sacramento do matrimonio de noite, nem abram as igrejas depois das Ave Marias para fazerem novenas, expor o Santíssimo Sacramento, e fazer outras devoções, do qual abuso temos ouvido que resulta na frequência de um, e outro sexo, naquelas horas, escândalo a toda cidade [...] E mandamos aos mesmos reverendos párocos, que na suas igrejas nem pratiquem, nem deixem praticar quaisquer novas, e extraordinárias devoções". Além de outras possíveis devoções que pudessem ocorrer nas igrejas, provavelmente o bispo já estava a indicar sobre os batuques, danças e outras expressões da cultura africana e crioula em Pernambuco. Ver mais em: Arquivo Nacional da Torre do Tombo. Real Mesa Censória, doc. D. Tomás da Encarnação Costa e Lima, cónego regrante de Santo Agostinho [...] Bispo de Pernambuco reprova a negociação no eclesiástico, dá conta da origem das vigílias e proíbe os festejos e novenas noturnas. p. 7

${ }^{38}$ CHITUNDA, 2014, p. 171.

${ }^{39}$ Idem.

${ }^{40}$ A documentação também se refere como "barbudinhos" ou "barbadinhos italianos".

${ }^{41}$ Laboratório de Pesquisa e Ensino de História (LAPEH). Arquivo Histórico Ultramarino, Pernambuco, Cx. 135, D. 10140.

${ }^{42}$ Laboratório de Pesquisa e Ensino de História (LAPEH). Arquivo Histórico Ultramarino, Pernambuco, Cx. 135, D. 10140

${ }^{43}$ RIBEIRO, Mônica da. "Razão de Estado" na cultura política moderna: o império português, ano 1720-30. In: ABREU, Martha; SOIHET, Rachel; GONTIJO, Rebeca (Orgs.). Cultura política e leituras do passado: historiografia e ensino de história. Civilização Brasileira, 2007, p. 134.

${ }^{44}$ RIBEIRO, 2007, p. 136.

${ }^{45}$ Provavelmente, era de conhecimento do governador. Em meados do século XVII, na Europa, a obra de Maquiavel era lida "sem licença nem escrúpulo". No século anterior, a Inquisição já havia proibido a leitura de sua obra. Mesmo religiosos e outras pessoas que possuíssem licença para ler as ideias de Maquiavel deveriam fazer em segredo absoluto. Para os agentes inquisitoriais, as ideias deste autor poderiam contaminar governadores e outros súditos. Acusavam que em seus escritos, os interesses do príncipe estavam à frente da religião e dos interesses da Igreja. Apesar disso, suas ideias tiveram ampla difusão na sociedade portuguesa. Sendo assim, não é difícil imaginar que muitos dos governadores ultramarinos baseavam-se nas teorias de Maquiavel para o bom funcionamento do seu governo. Para uma discussão sobre o assunto, ver: MONTEIRO, Rodrigo Bentes.; DANTAS, Vinícius. Maquiavelismos e governos na América portuguesa: dois estudos de 
ideias e práticas políticas. Revista Tempo. 2014, v. 20. Dossiê. Traduções de Maquiavel: da Índia portuguesa ao Brasil; Sobre a proibição de livros por parte da Inquisição, ver: RIBEIRO, Eneida Beraldi. A censura inquisitorial e o tráfico de livros e ideias no Brasil Colonial. Fênix - Revista de História e Estudos Culturai. Janeiro/ Fevereiro/ Março/ Abril de 2012 Vol. 9. Ano IX, $\mathrm{n}^{\circ} 1$.

${ }^{46}$ ALMEIDA, Érika Simões. A câmara do Recife e a coroa portuguesa: negociação de conflitos e conformação do pacto político no reinado de D. Maria I. In: Revista Trilhas da História. Três Lagoas, v.4, nº8 Jan-Jun, 2015, p.186-189.

${ }^{47}$ RIBEIRO, Mônica da. "Razão de Estado" na cultura política moderna: o império português, ano 1720-30. In: ABREU, Martha; SOIHET, Rachel; GONTIJO, Rebeca (Orgs.). Cultura política e leituras do passado: historiografia e ensino de história. Civilização Brasileira, 2007, p. 147.

${ }^{48}$ RIBEIRO, 2007, p. 133.

${ }^{49}$ Laboratório de Pesquisa e Ensino de História (LAPEH). Arquivo Histórico Ultramarino, Códice 583, fls. 222.

${ }^{50}$ Laboratório de Pesquisa e Ensino de História (LAPEH). Arquivo Histórico Ultramarino, Pernambuco, Cx. 137, D. 10245.

${ }^{51}$ Idem.

${ }^{52}$ CHITUNDA, 2014, p. 168-182.

${ }^{53}$ Sobre este assunto, ver: CHITUNDA, 2014.; REGINALDO, 2011.

${ }^{54}$ SOUZA, Laura de Mello. Revisitando o calundu". In: GORENSTEIN, Lina e CARNEIRO, Maria L. Tucci (Org.). Ensaios sobre a intolerância: Inquisição, Marranismo e Anti-Semitismo. São Paulo: Humanitas, 2002, p. 293-317.

55 Idem.

${ }^{56}$ CASTRO, Yeda Pessoa de. Falares africanos na Bahia - um vocabulário afro-brasileiro, Rio de Janeiro, Academia Brasileira de Letras / TopBooks, 2001, p. 192.

${ }^{57}$ Arquivo Histórico Ultramarino, Códice 583, fls. 221-221v.

${ }^{58}$ Laboratório de Pesquisa e Ensino de História (LAPEH). Arquivo Histórico Ultramarino, Códice 583, fls. 221$221 \mathrm{v}$.

${ }^{59}$ MINTZ e PRICE, 2003, p. 19.

${ }^{60}$ Laboratório de Pesquisa e Ensino de História (LAPEH). Arquivo Histórico Ultramarino, Códice 583, fls. 221 $221 \mathrm{v}$.

${ }^{61}$ CAVAZZI, João Antônio de Montecúccolo. Descrição histórica dos três reinos do Congo, Matamba e Angola. Junta de Investigação do Ultramar. Lisboa. 1965. p. 113.

${ }^{62}$ Laboratório de Pesquisa e Ensino de História (LAPEH). Arquivo Histórico Ultramarino, Pernambuco, Cx. 141, D. 10415 .

${ }^{63}$ Laboratório de Pesquisa e Ensino de História (LAPEH). Arquivo Histórico Ultramarino, Pernambuco, Cx. 138, D. 10259.

${ }^{64}$ HESPANHA, António Manuel. Antigo Regime nos trópicos? Um debate sobre o modelo político do império colonial português. In: FRAGOSO, João.; GOUVÊA, Maria de Fátima. Na trama das redes: política e negócios no império português, séculos XVI-XVIII. Rio de Janeiro: Civilização Brasileira, 2010, p. 50.

${ }^{65}$ HESPANHA, 2010, pp. 59-62.

\section{Fontes}

\section{Laboratório de Pesquisa e Ensino de História (LAPEH) Arquivo Histórico Ultramarino coleção avulsos}

Arquivo Histórico Ultramarino, CU-Diversos, Cx. 6, D. 476.

Arquivo Histórico Ultramarino, Pernambuco, Cx. 10, D. 999.

Arquivo Histórico Ultramarino, Pernambuco, Cx. 93, D. 7406.

Arquivo Histórico Ultramarino, Pernambuco, Cx. 96, D. 7564.

Arquivo Histórico Ultramarino. Pernambuco Cx. 129, D. 9760.

Arquivo Histórico Ultramarino. Pernambuco, Cx. 129, D. 9770.

Arquivo Histórico Ultramarino, Pernambuco, Cx. 130, D. 9816.

Arquivo Histórico Ultramarino, Pernambuco, Cx. 135, D. 10140. 
Arquivo Histórico Ultramarino, Pernambuco, Cx. 137, D. 10245.

Arquivo Histórico Ultramarino, Pernambuco, Cx. 138, D. 10259.

Arquivo Histórico Ultramarino. Pernambuco, Cx. 141, D. 10415.

Arquivo Histórico Ultramarino, Pernambuco, Cx. 148, D. 10763.

\section{Arquivo Histórico Ultramarino coleção códices}

Arquivo Histórico Ultramarino, Códice 583, fls. 190v-191

Arquivo Histórico Ultramarino, Códice 583, fls. 221-221v.

Arquivo Histórico Ultramarino, Códice 583, fls. 222.

\section{Arquivo Nacional da Torre do Tombo}

Arquivo Nacional da Torre do Tombo, Real Mesa Censória, doc. 6603.

Arquivo Nacional da Torre do Tombo, Ministério do Reino, mç. 599, nº 15.

Arquivo Nacional da Torre do Tombo, Processo no 1377-1.

Arquivo Nacional da Torre do Tombo, Processo $n^{\circ} 4740$.

\section{Fontes Impressas}

ANTONIL, André João. Cultura e opulência do Brasil. Belo Horizonte: Itatiaia/Edusp, 1982.

CAVAZZI, João Antônio de Montecúccolo. Descrição histórica dos três reinos do Congo, Matamba e Angola. Junta de Investigação do Ultramar. Lisboa. 1965.

\section{Referências Bibliográficas}

ALMEIDA, Érika Simões. A câmara do Recife e a coroa portuguesa: negociação de conflitos e conformação do pacto político no reinado de D. Maria I. In: Revista Trilhas da História. Três Lagoas, v.4, nº8 Jan-Jun, 2015.

ARAÚJO, Rita Cássia B. de. Cruzes, plumas e batuques: festas públicas e colonização na América portuguesa. Ci. \& Tróp. Recife, v. n. 2, p. 161-181. Jul/Dez, 2000.

BARTH, Fredrik. Grupos étnicos e suas fronteiras, In: POUTIGNAT, Philippe e STREIFFFNART, Jocelyne. Teorias da etnicidade. São Paulo: UNESP, 1998.

BERUTE, Gabriel Santos. O tráfico negreiro no Rio Grande do Sul e as conjunturas do tráfico Atlântico. C. 1790 - c. 1830. $5^{\circ}$ Encontro Escravidão e Liberdade no Brasil Meridional. 2012.

BURKE, Peter. Cultura popular na idade moderna. Europa, 1500-1800. São Paulo, Companhia das Letras, 1989. 
CASTRO, Yeda Pessoa de. Falares africanos na Bahia - um vocabulário afro-brasileiro, Rio de Janeiro, Academia Brasileira de Letras / TopBooks, 2001.

CHITUNDA, Paulo Alexandre Sicato. Entre missas e batuques: Irmandade Nossa Senhora do Rosário dos Homens Pretos em Recife, Goiana e Olinda - Século XVIII. Dissertação de Mestrado apresentado ao PPGHUFRN. Natal, 2014.

GUEDES, Roberto (Org.). Dinâmica Imperial no antigo Regime Português: escravidão, governos, fronteiras, poderes e legados: século XVII - XIX. Rio de Janeiro: Mauad X, 2011.

HESPANHA, António Manuel. Antigo Regime nos trópicos? Um debate sobre o modelo político do império colonial português. In: FRAGOSO, João; GOUVÊA, Maria de Fátima. Na trama das redes: política e negócios no império português, séculos XVI-XVIII. Rio de Janeiro: Civilização Brasileira, 2010.

MAYOR, Mariana Soutto. O teatro do século XVIII no Brasil: das festas públicas às casas de ópera. Revista aSPAs. Vol. 5. n. 2. 2015.

MELlO E SOUZA, Marina de. Reis negros no Brasil escravista. História da festa de coroação de Rei Congo. Belo Horizonte, Editora da Universidade de Minas Gerais, 2002.

MELLO, José Antônio Gonsalves de. Um Governador colonial e as seitas africanas. Diário de Pernambuco. Recife, 22 Jan. 1950.

MINTZ, Sidney.; PRICE, Richard. O nascimento da cultura afro-americana: uma perspectiva antropológica. Rio de Janeiro; Pallas; Universidade Candido Mendes, 2003.

MONTEIRO, Rodrigo Bentes.; DANTAS, Vinícius. Maquiavelismos e governos na América portuguesa: dois estudos de ideias e práticas políticas. Revista Tempo. 2014, v. 20.

ORO, Ari. Religiões Afro-Brasileiras do Rio Grande do Sul: passado e presente. Estudos Afro-Asiáticos, Ano 24, nº 2, 2002, pp. 345-384.

REGINALDO, Lucilene. Os rosários dos angolas: irmandades de africanos e crioulos na Bahia setecentista. São Paulo: Alameda, 2011.

REIS, João José. Batuque Negro: repressão e permissão na Bahia oitocentista. In: JANCSÓ, István; KANTOR, Iris (Orgs.). Festa: cultura e sociabilidade na América Portuguesa. São Paulo: Hucitec, 2001.

REIS, João José. Revisitando "Magia jeje na Bahia". In: COSTA, Valéria Gomes.; GOMES, Flávio. Religiões negras no Brasil: da escravidão à pós-emancipação. Editora: Selo Negro, 2016.

RIBEIRO, Eneida Beraldi. A censura inquisitorial e o tráfico de livros e ideias no Brasil Colonial. Fênix - Revista de História e Estudos Culturais Janeiro/ Fevereiro/ Março/ Abril de 2012 Vol. 9. Ano IX, no 1. 
RIBEIRO, Mônica da. "Razão de Estado" na cultura política moderna: o império português, ano 1720-30. In: ABREU, Martha; SOIHET, Rachel; GONTIJO, Rebeca (Orgs.). Cultura política e leituras do passado: historiografia e ensino de história. Civilização Brasileira, 2007.

SILVA, Kalina Vanderlei. O teatro urbano - sociabilidades urbanas açucareiras em Pernambuco nos séculos XVII e XVIII. CLIO: Revista de Pesquisa Histórica, n. 29.2 (2011).

SILVA, Luiz Geraldo. "Da festa barroca à intolerância ilustrada: Irmandades católicas e religiosidade negra na América portuguesa (1750-1815)". In: SALLES-REESE, Verónica (Org.). Repensando el pasado, recuperando el futuro: nuevos aportes interdisciplinarios para el estúdio de la América colonial. Bogotá: Editorial Pontifcia Universidad Javeriana.

SLENES, Robert W. "Malungu, ngoma vem!": África coberta e descoberta do Brasil. In: Cadernos do Museu da Escravatura, n. 1. Ministério da Cultura. Luanda, 1995.

SOUZA, Laura de Mello. Revisitando o calundu". In: GORENSTEIN, Lina e CARNEIRO, Maria L. Tucci (Org.). Ensaios sobre a intolerância: Inquisição, Marranismo e AntiSemitismo. São Paulo: Humanitas, 2002,

SWEET, James H. Recriar África: cultura, parentesco e religião no mundo afro-português (1441-1770) / James H. Sweet; Trad. João Reis Nunes; Luís Abel Ferreira. Lisboa: Edições 70, 2007.

TOLEDO, Cézar de Alencar Arnaut de; RUCKSTADTER, Flávio Massami Martins; RUCKSTADTER, Vanessa Campos Mariano. O teatro jesuítico na Europa e no Brasil no século XVI. Revista HISTEDBR On-line, Campinas, n.25, mar. 2007.

VALE, Fernanda Cristina. Linguagens de amor: a feitiçaria como meio de conquista amorosa no Brasil colonial. III Seminário Linguagem e Identidades: múltiplos olhares. 